Article

\title{
Scrutinising Multidimensional Challenges in the Maloti-Drakensberg (Lesotho/South Africa)
}

\author{
Jess L. Delves ${ }^{1,2, * \mathbb{C}}$, V. Ralph Clark ${ }^{3}$, Stefan Schneiderbauer ${ }^{1,2,3}{ }^{\oplus}$, Nigel P. Barker ${ }^{4}{ }^{\oplus}$, Jörg Szarzynski ${ }^{1,2,3,5}$, \\ Stefano Tondini ${ }^{6}\left(\mathbb{D}\right.$, João de Deus Vidal, Jr. ${ }^{3}$ and Andrea Membretti ${ }^{3,7}$
}

check for

updates

Citation: Delves, J.L.; Clark, V.R.; Schneiderbauer, S.; Barker, N.P.; Szarzynski, J.; Tondini, S.; Vidal, J.d.D., Jr.; Membretti, A. Scrutinising Multidimensional Challenges in the Maloti-Drakensberg (Lesotho/South Africa). Sustainability 2021, 13, 8511. https://doi.org/10.3390/su13158511

Academic Editors: Harald Pechlaner, Paola Fontanella Pisa and Felix Windegger

Received: 27 May 2021

Accepted: 26 July 2021

Published: 30 July 2021

Publisher's Note: MDPI stays neutral with regard to jurisdictional claims in published maps and institutional affiliations.

Copyright: (c) 2021 by the authors. Licensee MDPI, Basel, Switzerland. This article is an open access article distributed under the terms and conditions of the Creative Commons Attribution (CC BY) license (https:/ / creativecommons.org/licenses/by/ $4.0 /)$.
1 Center for Global Mountain Safeguard Research (GLOMOS), Institute for Environment and Human Security, United Nations University, 53113 Bonn, Germany; Stefan.Schneiderbauer@eurac.edu (S.S.); szarzynski@ehs.unu.edu (J.S.)

2 Eurac Research, Center for Global Mountain Safeguard Research (GLOMOS), Bolzano Office, 39100 Bozen/Bolzano, Italy

3 Afromontane Research Unit (ARU), Department of Geography, QwaQwa Campus, University of the Free State, Phuthaditjhaba 9866, South Africa; ClarkVR@ufs.ac.za (V.R.C.); jd.vidal@unesp.br (J.d.D.V.J.); andrea.membretti@uef.fi (A.M.)

4 Department of Plant and Soil Sciences, University of Pretoria, Pretoria 0002, South Africa; nigel.barker@up.ac.za

5 Disaster Management Training and Education Centre for Africa (DiMTEC), University of the Free State (UFS), Bloemfontein 9310, South Africa

6 Center for Sensing Solutions, Eurac Research, 39100 Bozen/Bolzano, Italy; Stefano.Tondini@eurac.edu

7 Faculty of Social Sciences and Business Studies, Karelian Institute, University of Eastern Finland, FI-80100 Joensuu, Finland

* Correspondence: delves@ehs.unu.edu

Abstract: The Maloti-Drakensberg (MD) is the largest and highest-elevation mountain system in southern Africa. Covering 40,000 $\mathrm{km}^{2}$ and reaching $3500 \mathrm{~m}$, the MD provides a range of ecosystem services (ES) to the entire southern African region-benefitting diverse users and extending well beyond the mountains. Rapid socioecological change threatens the provision of ES and presents multidimensional challenges to sustainable development. However, the continued land degradation and persisting socioeconomic problems indicate that development policy has not been effective in tackling these issues. In this paper, a multidisciplinary literature review forms the basis of a discussion which takes an ES framing to scrutinise the multidimensional social, political, economic and cultural issues in the study area. Three critical management systems are presented, and their associated ES are discussed, namely, water transfer, rangelands and conservation and tourism. In particular, the diversity of ES uses and values in the MD is considered. The results reveal the main drivers of continued unsustainable development and highlight important information gaps.

Keywords: traditional authorities; governance systems; land use; Lesotho Highlands Water Project; overgrazing

\section{Introduction}

Sustainable development requires a holistic and integrated approach, which includes the needs of diverse groups in policy and planning, and decision makers depend on research to inform such policies. However, research in the Maloti-Drakensberg (MD) mountains tends to be discipline-focussed and not address the complexity of multidimensional and multidisciplinary issues, leaving policy makers with gaps in understanding of interconnected issues. Based predominantly on literature review, this paper provides a much-needed synthesis of the major challenges affecting sustainable development in the study area. It makes use of the multidisciplinary concepts of ecosystem services and sustainability in order to present findings in a way that is accessible to readers from diverse disciplinary backgrounds. 
The Maloti-Drakensberg is a transboundary mountain range which provides ecosystem services (ES) to both local and distant communities. The mountains act as a 'water tower' which captures, stores and filters water, providing more than 12 million people with water and fuelling South Africa's industrial heartland in Gauteng province [1]. Rangeland and arable land provide subsistence livelihoods for many of the rural inhabitants, although soil erosion-due in large part to overgrazing - threatens these livelihoods along with the supply of water downstream [2,3]. Protected natural areas seek to conserve water resources, biodiversity and endemism. However, differing land use values between conservationists, local farmers and private business can result in conflict, especially in an area of high poverty and inequality. Protected areas are marketed by the tourism industry for their recreational and cultural ES, the economic benefits of which can fund local development. The interrelation of these groups with their mountain environment represents complex systems in which multiple stakeholders depend to varying degrees on ES. At the same time, a trend of ecosystem degradation forms negative feedback loops wherein decreasingly productive land is used more intensively without an increase in output. In addition, the mountain environment is particularly sensitive to the impacts of global climate change $[4,5]$ increasing the uncertainty of the future provision of ES.

Sustainable development requires an integrated and interdisciplinary approach [6], but research in the study area is often monodisciplinary. Our research revealed that the barriers to sustainable development in the MD are complex, multi-dimensional and interdependent. However, policy regarding ES is dominated by mainstream economic ideas which obfuscate alternative perspectives, uses or valuations of ES. To inform fair and sustainable policy that accounts for the diversity of needs of ES users, we argue that an interdisciplinary approach to research in the MD is essential.

The objective of the research is to examine the multifaceted and multidimensional issues in the MD relating to the sustainability of its ecosystem services. The purpose of this paper is to provide insight into the diversity of values attached to ES and reveal research and policy gaps relating to sustainable development in the study area. In an underresearched region where this level of interdisciplinary research has not been conducted before, this paper offers a new, holistic perspective on research in the MD.

\section{Materials and Methods}

\subsection{Methods}

The objective of this research is to scrutinise the multidimensional issues affecting sustainable development in an area of the Maloti-Drakensberg mountains. An ecosystem services framing is used to scrutinise the interconnected and multifaceted nature of these issues.

Key ecosystem services were identified through a combination of desk research and informal interviews in the field and remotely with local researchers, traditional leaders and other stakeholders (park managers, tourism operators, charity workers). To understand the current state of scientific research in the study area, a systematic literature search was performed. The results give an overview of the dominant research disciplines and topics in the study area.

A second phase consisted of collecting and qualitatively analysing literature pertaining to ES management and use. This was initially done through extracting articles from the systematic literature search. However, there is a general paucity of such literature due to the fact that the MD is a remote, developing and under-researched area. From the core of the systematically collected literature we therefore employed more qualitative literature search methods, namely snowball method, internet searches and informal interviews (with researchers, government officials and stakeholders). Grey literature was also included in this phase. Demographic data were collected from official censuses where possible or from secondary sources (i.e., research and reports), as were data on livestock numbers. Data and reports regarding some of the protected areas were provided by managers of the provincial (Ezemvelo KwaZulu-Natal) and national parks (SANParks) in South Africa. 
Data collection in the different municipalities in the study area has been unsystematic due to changing administrative borders, changes in collection methods, lack of resources and undocumented people. Due to this, data from different indicators were available over different timeframes and from different sources with varying levels of reliability. Generally speaking, data collection from 1960s onwards becomes more systematic although there remain gaps and inconsistencies in reporting. Throughout the research process, data was always verified through secondary sources or through local informants.

\subsection{Concept: Ecosystem Services}

Definitions of ecosystem services differ and have been evolving since its first use in the 1980s. However, at the core of all definitions are the linkages between human well-being and ecosystems, with ecosystem services being the 'bridge' between the-conceptually separate but practically inseparable_-'human world' and 'natural world'. Definitions broadly fall into two categories, those which consider ES as being "the conditions and processes through which natural ecosystems and their species sustain and fulfil human life," and those which emphasise the economic importance of ES as "the benefits humans derive, directly or indirectly, from ecosystem functions" [7]. Furthermore, frameworks have different approaches to categorisation, classification and mensuration, making comparisons between studies which apply different frameworks difficult.

The Common International Classification of Ecosystem Services (CICES) was proposed in 2009 to serve as a reference classification to allow translation between different ecosystem classification systems. As such, it is regularly updated in order to account for developments in ES approaches. It seeks to reflect or incorporate elements of the most prominent ES initiatives, namely: Millennium Ecosystem Assessment (MEA) [8], The Economics of Ecosystems and Biodiversity (TEEB) [9] and the Intergovernmental Platform for Biodiversity and Ecosystem Services (IPBES) [10]. CICES employs the most widely used terminology and categorises ES into the three services provisioning, regulating $\mathcal{E}$ maintenance and cultural services [11]. Following on from the EU MAES Process, CICES V5.1 (2018) explicitly includes abiotic ecosystem outputs, i.e., not those ecosystem services that depend on living systems but rather those that depend on physical systems that are part of nature. This allows for the logically coherent consideration of outputs such as water, wind power, salt and snow as 'ecosystem services', whereas they would previously be considered natural resources or natural capital. In this way, CICES V5.1 includes a broad spectrum of natural resources and processes that human societies draw upon. Because it provides a comprehensive and up-to-date index of ecosystem services that reflects the current state of research in the field, CICES was chosen as the classification framework for this paper.

In general, the ecosystem services concept is applied in this paper as it provides a framing that is accessible and applicable by a range of stakeholders involved in sustainable development, be they scientists, practitioners or non-specialists.

\subsection{Concept: Sustainable Development}

Sustainable development as a concept unites concerns about the future of humanity and the planet, treating environmental health as inseparable from socioeconomic issues such as poverty and well-being. The most frequent definition of sustainable development originates from the 1987 Brundtland Report, which describes it as "development which meets the needs of the present without compromising the ability of future generations to meet their own needs" [12]. Commonly, three aspects of sustainability are considered: economic, social and environmental. Many definitions exist and may include additional aspects, for example the UNWTO refers to 'socio-cultural' sustainability in tourism [13]. Sustainable development is employed in this paper as a critical framing for the analysis of multiple issues relating to ecosystem services. 


\section{Results and Discussion}

\subsection{Systematic Literature Search}

A search query specifying the geographic area was run through six major search systems (Figure 1), without specifying a date range. This initial search returned 3248 results. It revealed a majority of research from the natural sciences $(51 \%)$, with social sciences and applied sciences representing $32 \%$ and $16 \%$, respectively (Figure 1 ). Research categorised as 'interdisciplinary' accounted for 1\%.

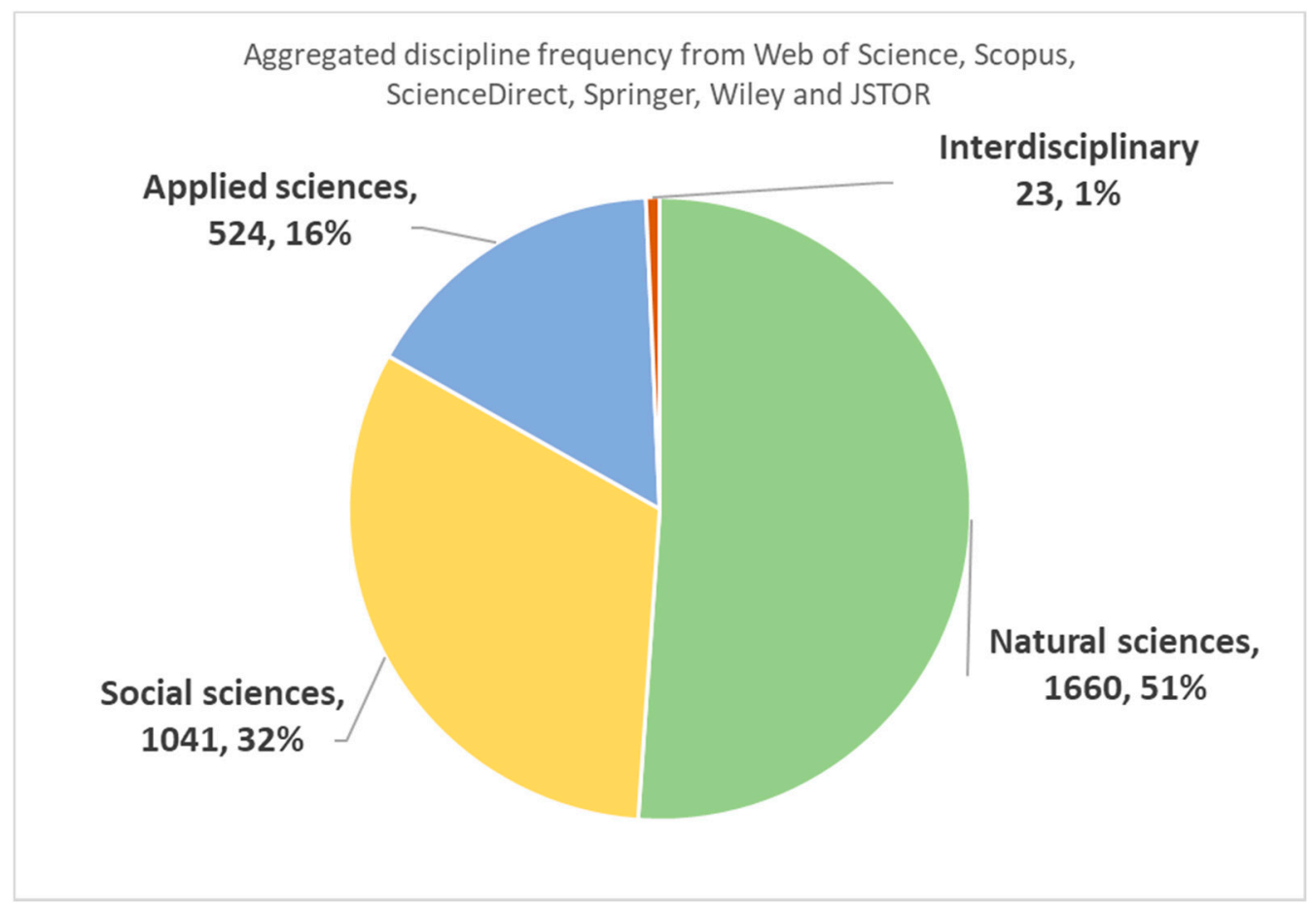

Figure 1. Aggregated data of discipline frequency showing absolute frequency and percentage of total. Search from Web of Science, Scopus, ScienceDirect, Springer, Wiley and JSTOR for the search query ("Qwa?Qwa" OR Phuthaditjhaba OR "Mal?ti Drakensberg" OR “Lesotho highlands").

Most of the research in this region has been discipline-focussed, predominantly in the areas of ecology and biodiversity [14], geology [15], pathology [16] and archaeology [17]. Even typically multidisciplinary research (e.g., in environmental science [18], sociology [19], area studies [20]) tends to rely on one discipline's methodology (see, e.g., Büscher, 2013 [21]). Research is weighted towards natural sciences and very little research is categorised as 'interdisciplinary' (Figure 1).

There is a lack of research which investigates the governance systems in the area, for example in the fields of sociology or public policy. There is also a paucity of research in medicine and public health. There is little research, particularly in the last two decades, from disciplines dealing with contemporary cultural heritage and identity, such as anthropology, linguistics or cultural studies. Recent literature remains mostly mono-disciplinary, with some exceptions including Showers 2005 [22], Blignaut et al. 2008, 2010 [23,24] and Nel et al. 2017 [25].

\subsection{The Maloti-Drakensberg Mountains}

The entire Maloti-Drakensberg mountains cover some $40,000 \mathrm{~km}^{2}$ as a transboundary system shared by the Kingdom of Lesotho and the Republic of South Africa [26]. Reaching $3482 \mathrm{~m}$ above sea level, the Maloti-Drakensberg is the highest mountain system in Africa south of Mount Kilimanjaro and forms the most dramatic part of the $5000 \mathrm{~km}$-long Great Escarpment system in southern Africa [27]. 
The study area comprises part of the northern Maloti-Drakensberg. Literature was analysed which addresses issues in an area centred on Mont-aux-Sources peak and a radius of $60 \mathrm{~km}$ around this that includes Golden Gate and Royal Natal Highlands National Park; QwaQwa, Mweni and Upper Tugela regions; the urban centres of Phuthaditjhaba, Clarens and Harrismith; and the adjacent Lesotho uplands and lowlands (Figure 2). This area was chosen due to the convergence of different forms of governance, national and provincial/district boundaries (in both countries) and the associated social-political-ecological complexities which represent significant challenges in territorial management and development planning. It is divided administratively across many dimensions: it is a trans-national region, encompassing two provinces in South Africa (Free State and KwaZulu-Natal [KZN]) and three districts in Lesotho (Butha-Buthe, Leribe and Mokhotlong).

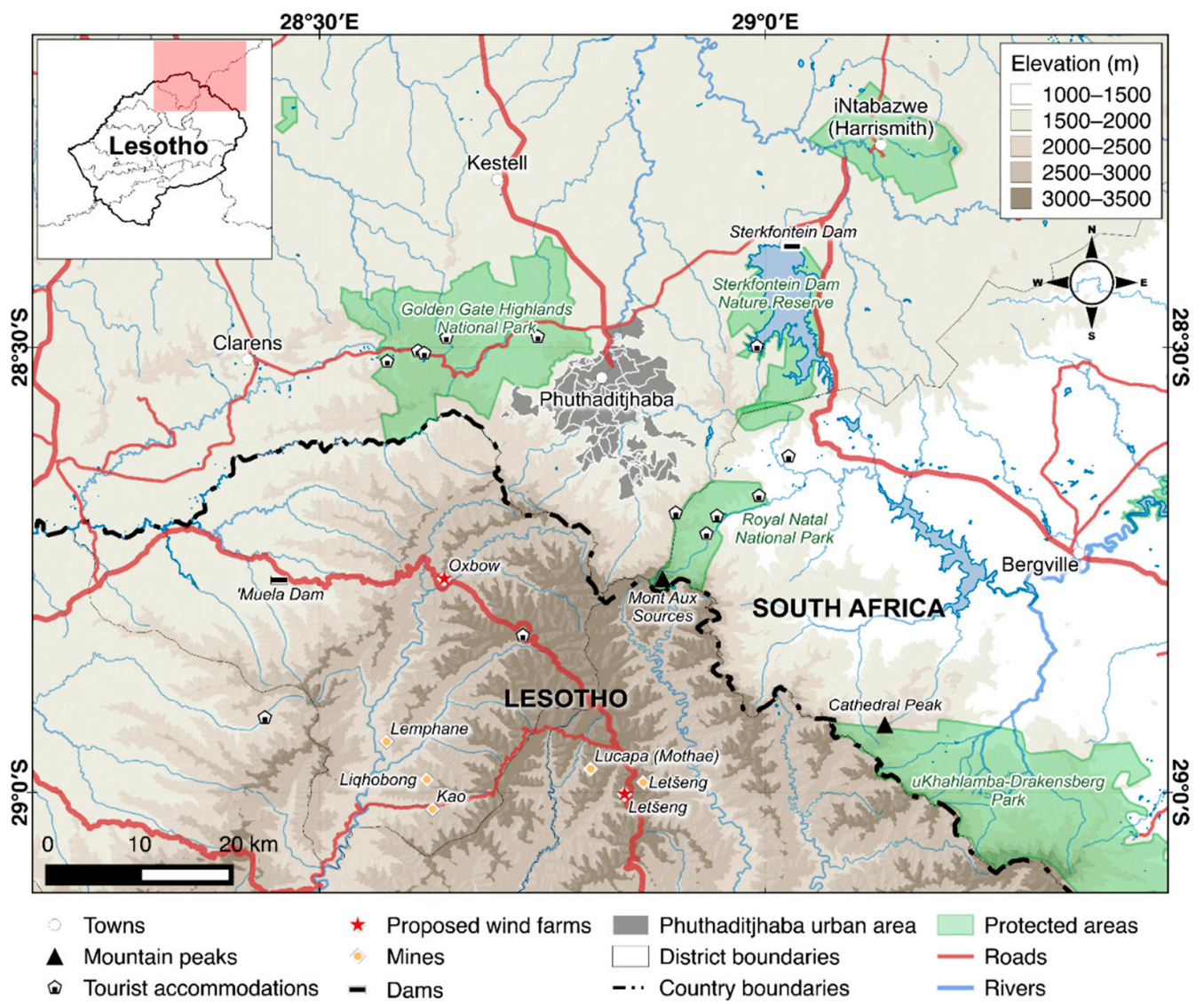

Figure 2. Map showing the study area. Map creator: João de Deus Vidal Júnior.

In the highlands of Lesotho there is little urban development except scattered rural villages and population density is low at $57 / \mathrm{km}^{2}$ (Figure $3 \mathrm{~b}$,d). Almost all land is treated as common land used for grazing of sheep, goats, cattle and horses ('Basotho ponies'). Forty-three percent of households in the mountains depend on subsistence agriculture, which also comprises rainfed crops (predominantly maize, sorghum and wheat) that are grown around villages (see Figure 3b) and on terraces lower in the valleys (Figure 3c) [28]. However, due to the mountainous terrain and steep topography, only $2.5 \%$ of Lesotho's territory is used for cultivating crops [29]. With some exceptions, officially protected natural areas are not managed or conserved, allowing herders to graze their livestock freely. The mean annual precipitation in the Maloti mountains is $1200 \mathrm{~mm}$, with $85 \%$ of the precipitation coming from rainfall, the majority of which occurs from October-March [30]; the remainder of the precipitation is in the form of snow, mostly between May and October annually. National poverty levels are high at $49.7 \%$. Nevertheless, Lesotho leads Africa on adult literacy rates (97\%) and gender parity in education [31-33]. 

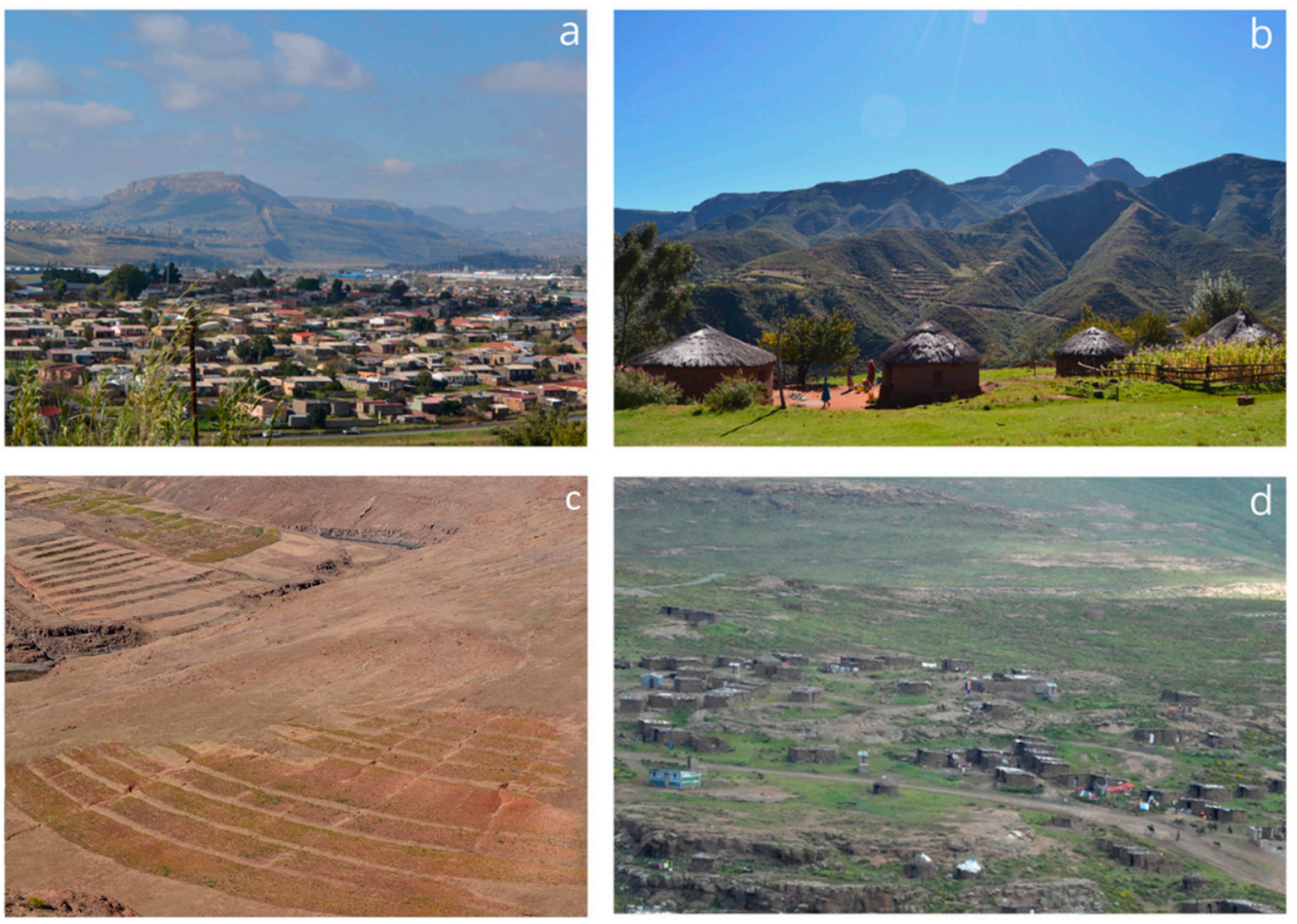

Figure 3. Images showing the study area. (a) Phuthaditjhaba, South Africa. (b) A Basotho village, Lesotho. (c) Agricultural terraces, Lesotho. (d) Mine workers' housing, Lesotho. Photos: (a-c) A. Membretti (d) J. Szarzynski.

In the South African lowlands lies the former Bantustans of QwaQwa (in the Free State, and the smallest homeland) and KwaZulu (in KwaZulu-Natal, and one of the largest homelands), two of thirteen former land reserves set aside during apartheid rule to which Black populations were forcibly removed. The capital city of former QwaQwa, Phuthaditjhaba, is located at the foot of the Maloti-Drakensberg, in the area colloquially referred to as the 'QwaQwa sandwich' - so named due to topographical or administrative barriers that limit the spatial growth of the city. Phuthaditjhaba developed rapidly and haphazardly under apartheid rule in the 1960s and 1970s and today has an official population of 275,000 with a density of $1615 / \mathrm{km}^{2}$ (Figure 3a), although unofficial estimates put the population between 400,000 to 500,000 . To the east and northwest, protected natural areas prohibit urban or agricultural development. To the north, the city is surrounded by extensive, private and predominantly White-owned farmland. To the south, the steep slopes of the Drakensberg make urban development virtually impossible. The lowlands are dependent on many mountain ES, most notably for water, and the study area forms part of the World Wildlife Fund's 'Northern Strategic Water Source Area' [34]. Settlements in the lowlands lack infrastructure and services. For example, in 2011 in Phuthaditjhaba's municipality, only $30 \%$ of households had a flush toilet connected to sewerage, only $25 \%$ had weekly refuse removal and only $32 \%$ had piped water inside the dwelling (compared to national average of $58 \%, 66 \%$ and $90 \%$, respectively) [35].

\subsubsection{Social-Political Contexts in the Study Area}

The study area has dual governance systems of elected government (represented by tiered local government to national government structures) and Traditional Authorities, operating in tandem and often in competition. Traditional Authorities are presented by the Lesotho Royal House in Lesotho, the Zulu Royal House in KwaZulu-Natal (practically represented by the Ingonyama Tribal Trust in Mweni and Upper Tugela) and two Royal Houses in QwaQwa-Bakoena and Batlokoa. The main ethnic groups-whose occupation of the area long predates modern nation states [36] —are the Sesotho (QwaQwa), Basotho 
(Lesotho) and isiZulu (KwaZulu-Natal); smaller populations of Whites, other African nationalities and people of Asian origin are also present [37,38]. Land ownership is a patchwork of communal, private, and state-owned land, with complicated administration structures, which are often ambiguous or contested [39,40]. The area has a complicated tribal and political history, with different experiences of the Mfecane (major tribal unrest mid-1800s) and European colonisation [41]. For example, Lesotho remained a traditional monarchy as a British Protectorate ('Basutoland'), while the indigenous populations in today's South Africa were overtly oppressed under colonialism and apartheid. Current land distribution and land use is characterised by great heterogeneity resulting from these colonisation processes.

Under apartheid rule in South Africa, policies of racial segregation were aggressively and radically enforced from 1948 until the early 1990s, under the ideologies of Afrikaner nationalism and White supremacy. The advent of universal suffrage in 1994 marked the dismantling of racist legislation. Following the 1959 Promotion of Bantu Self-Government Act [42], 70\% of South Africa's population was forcibly removed to Bantustans that covered only $13 \%$ of the national territory. In theory, the Bantustans ran their own affairs without any share in the wider South Africa [43]. In practice, South Africa maintained control through its appointment of cooperative traditional leaders (see article 6, Promotion of Bantu Self-Government Act, Act No 46 of 1959).

In the QwaQwa Bantustan, the population exploded from 24,000 to 300,000 between 1970 and 1980 [44]. The Bantustan was wedged between officially protected natural areas and agricultural land from which settlement was excluded. The majority of people removed to QwaQwa found themselves crowded in "areas urban in density of population and lack of agricultural land, but devoid of urban employment or services" [44]. Service provision continues to be inadequate in Phuthaditjhaba (the former capital). A water shortage crisis in summer 2019-2020 followed two years of a pronounced drought and late rain period across southern Africa, compounded by chronic underinvestment in infrastructure and mismanagement at the local municipal level [45].

\subsection{Key Ecosystem Services}

Identifying key ecosystem services in the MD was an iterative process combining desk research with exchanges with local experts. In order to identify the ES relevant to our research, previous ES research carried out in the study area was selected from the literature search $[23,40,46-49]$.

There is a lack of systematic quantitative ecosystem service accounting, mapping or monitoring in the MD, which would inform policy on sustainable development and allow for comparison of ecosystem service provision between protected and non-protected areas. In the early 2000s, the Maloti Drakensberg Transfrontier Park (MDTP)—a transboundary conservation area covering $14740 \mathrm{~km}^{2}$ and most of the study area-commissioned a report into the feasibility of a Payment for Ecosystem Services (PES) scheme [46]. The baseline report and related research provides some quantitative assessment of ES in part of the study area. Other research has also classified or described other ecosystem services, environments or related processes, namely hydrological modelling in the Upper uThukela catchment [23] and montane wetland vegetation across the MD [50,51]. Since the proposed PES scheme, and in step with a general increase in ES research globally, research output addressing ES issues in the MD has increased but remains mostly qualitative or theoretical. In addition, no research takes a gendered approach and considers how impacts in changes to ES provision may affect genders differently.

In the MD, there are three principal management systems which govern access to ES and influence their provision. The competing interests and unequal power dynamics between land users and managers has often led to conflict when land management by one group impacts the ES used by another. This paper is structured around these three management systems, namely: Water transfer (managed by the Lesotho Highlands Water Project (LHWP) and Lesotho Highlands Development Agency (LHDA)), Rangelands and 
Conservation and tourism. Under each category, key ES services are identified, and the sustainability of their management considered.

\section{Water transfer}

Southern Africa is a water stressed region [52]. The MD is an important 'water tower', capturing, storing and filtering water which is slowly released during the dry season. Management of this resource is crucial as predicted warmer temperatures will likely exacerbate water scarcity in the region [53]. Considering the current and future importance of water in the region, the control of high catchment areas is a politically charged issue. The LHWP is a multi-billion-dollar project initiated in the 1980s which dams and diverts water from Lesotho to South Africa and has raised concerns regarding ecosystem degradation, the displacement of indigenous populations, access to and control of productive resources and Lesotho's national sovereignty.

\section{Rangelands}

Rangeland provides the basis for subsistence farming for many of the highland inhabitants. At the same time, overgrazing is degrading the land and affecting water availability and quality downstream. Overexploitation also has implications for plant populations sensitive to grazing and the invertebrate fauna that depend on them. Rangeland management is a key issue where differences in traditional and modern management practices cause conflict between the many land users and managers.

\section{Conservation and tourism}

Conservation areas have been established in the MD since the beginning of the 20th century, sometimes excluding inhabitants that depend on the ES these areas provide. Increasingly, there is also demand for recreational mountain activities from locals and visitors. Increased tourist numbers raise questions about the role of the industry in the local communities and the demands it places on land and resources.

Ecosystem services depend on living systems, that is, biodiversity in its broadest sense [54]. The three management systems in the MD affect biodiversity in different ways, either through concerted efforts to preserve or enhance it (as in conservation practices), or through environmentally unsustainable practices which reduce biodiversity. What follows is a brief description of biodiversity in the study area.

\subsection{Biodiversity}

\subsubsection{Biodiversity and Rangelands}

Natural rangelands cover the vast majority of the study area and comprise important areas for in situ conservation of MD's endemic-rich biodiversity, as well as being a vital form of food security (mostly livestock) in a region with limited arable land and limited dryland cropping potential [2,55-58]. Well-managed rangelands are the most successful and cheapest form of conservation in grassland-dominated ecosystems, such as the MD. The region has long been recognised as a centre of plant diversity and endemism, known as the Drakensberg Mountain Centre, with approximately $9 \%$ of the species considered to be endemic [26]. Wild plants are harvested for products which are sold locally, for example brooms made from the riparian grass Merxmuellera macowanii. Interestingly, a species considered invasive and in need of eradication by conservationists (Sweet-Briar, Rosa rubiginosa) is harvested by locals for its oil (which is exported to Europe) and juice. Similarly, Crack Willow (Salix fragilis) (also invasive and which are water-expensive compared to natural riparian vegetation) provides fuelwood (where previously dried cow dung was used in the highlands) and timber for construction.

The MD also has considerable levels of endemic animals. For example, Hamer and Slowtow (2009) [59] found that $85 \%$ of millipede samples from the Maloti-Drakensberg were restricted to that region. Three species of birds are considered endemic, with several near-endemic species [60]. Three-hundred-and-ninety-three species of Lepidoptera have been recorded from Lesotho. This represents $13 \%$ and $3.7 \%$ of southern African butterflies 
and moths, respectively, many of which are probably endemic or near-endemic to the MD region [61].

\subsubsection{Drivers of Biodiversity Loss}

Overgrazing is frequently blamed for land degradation and biodiversity loss in the study area (Figure 4). This claim has been alternately refuted and confirmed (see, e.g., Büscher, 2013 [21]; Driver, 1999 [55]; Makhoalibe, 1999 [30]; ORASECOM, 2014 [57]; Quinlan, 1995 [62]; Rohde et al., 2006 [2]; Showers, 2005, 1989 [22,63]; Slater, 2002b [64]; Turpie et al., 2008 [48]). That stock levels are unsustainably high is, however, undisputed.

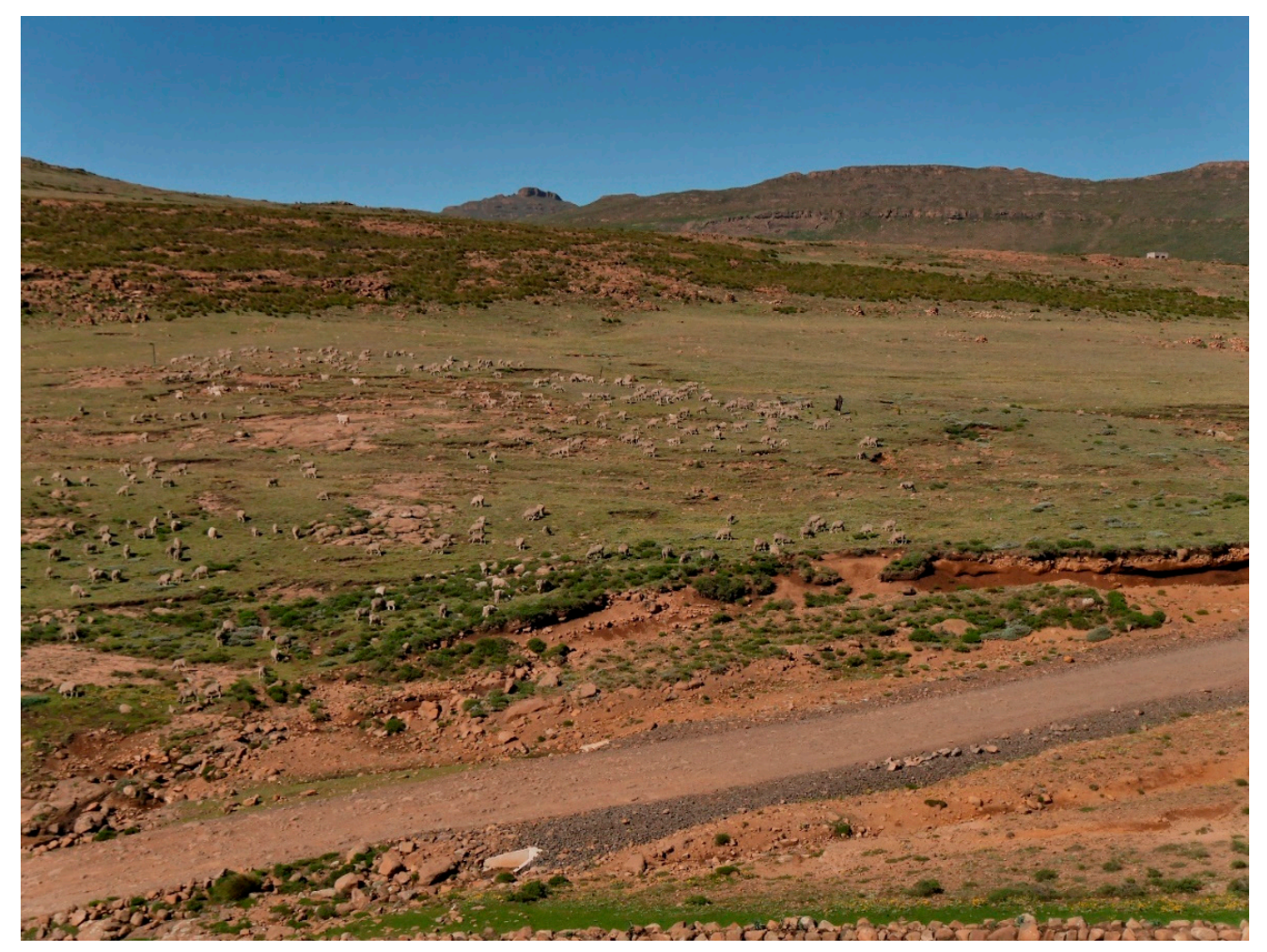

Figure 4. Rangeland showing signs of erosion being grazed in Lesotho. Photo: S. Schneiderbauer.

What was once good grazing rangelands with Red Grass (Themeda triandra) (up to $2500 \mathrm{~m}$ ) and Festuca spp. (above $2500 \mathrm{~m}$ ) have become invaded with unpalatable shrublets including Chrysocoma ciliate, Eumorphia sericea and Helichrysum trilineatum, greatly increasing the risk of bush encroachment. In the absence of clear integrated rangeland management, some farmers employ short-sighted management practices such as the burning of rangeland to improve winter grazing [57]. Although fire is part of the natural cycle of grasslands, excessive burning leaves soil exposed to erosion and does not effectively control the invasion of shrubs [24,57]. During the winter following the fires, heavy grazing reduces vegetation cover further and exposes soil to spring rains.

The Lesotho Highlands Water Project (LHWP), described in the following section, is having considerable negative impacts on biodiversity in the MD. A recent environmental assessment predicts 'major' and 'moderate' long-term negative impacts to downstream river ecosystems (from the Senqu River to confluence with Malibamatso), as well as 'critical' or 'major' negative impacts to surrounding wetlands, which are critical for water retention and filtration [65]. It is also predicted that the dam will impact other ecosystem services through the destruction of habitat of local flora and fauna, with particularly negative impacts on cliff nesting birds upstream and fish populations both up- and downstream [65]. Increased pressure on rangelands and wetlands will result from the displacement of communities for the reservoir construction, exacerbating erosion and land degradation [65]. 
Alien and invasive species also compete with native flora and fauna. Alien trout (Oncorhynchus mykiss and Salmo trutta), introduced in the late 1800s for commercial and recreational fishing, have severely impacted the populations of Maluti Redfin (Pseudobarbus quathlambae) in Lesotho [66] and the indigenous Natal Cascade frog (Hadromophryne natalensis) in the uKhahlamba-Drakensberg Park [67].

Research, accounting and monitoring of biodiversity is a prominent field in the literature, and therefore data is available on plant and animal populations in specific areas, however, this is not comprehensive. According to Carbutt and Edwards (2015), missing from the research is a consideration of below-ground drivers for changes in biodiversity, as research tends to focus on above-ground drivers such as fires and herbivory [68]. A national scale map of soil erosion in South Africa was published in 2008 and could form the basis of further research into the cascading impacts of erosion on biodiversity [69]. A key knowledge gap is the identification and mapping of areas in which overgrazing is degrading land and biodiversity in Lesotho. Such an exercise would be indispensable to identify priority areas of intervention for sustainable development and protection not only of biodiversity but also other ecosystem services.

\subsection{Water Transfer \\ Lesotho Highlands Water Project}

Freshwater capture, filtration, storage and flow regulation are vital ES provided by the Maloti-Drakensberg mountains. They not only supply drinking water to local and distant populations, but also water used in agriculture and industry. The MD mountains are therefore of fundamental importance for national and local economies [24]. However, according to the UN definition, South Africa is a water-stressed country [70,71] with increasing demand that is expected to outstrip supply in future [72]. South Africa has therefore sought to control the mountain water catchment areas, and since the 1970s, transnational water transfer infrastructure projects have redirected water from Lesotho to South Africa. Water management in the region presents important sustainability tradeoffs: the economic and societal importance of water export is in contention with the ecosystem degradation caused by water infrastructure, as well as the sociocultural impact on affected communities.

The largest water transfer project, the Lesotho Highlands Water Project (LHWP), was initiated in 1986 following decades of failed negotiations. From the outset, the project has been embroiled in geopolitics. In the 1980s, severe droughts in South Africa had increased demand for water, but the Prime Minister of Lesotho at that time insisted on maintaining control over water flow in Lesotho [73]. His removal in a South African-backed military coup in January 1986 cleared the way for the signing of the LHWP treaty.

Today, the LHWP is key to the economies of both countries. Its primary beneficiaries are the more than 12 million South Africans in the Greater Johannesburg Metropolitan areas, whose water arrives from the Lesotho highlands. As a provisioning ES, this water also fuels South Africa's industrial heartland in Gauteng province (Figure 5, insert) [1] and generates power at the 'Muela hydropower station. Lesotho receives royalties from South Africa for water, estimated in 2001 at USD 44 million [74], and also sells electricity produced by the 'Muela hydropower station to Eskom, the South African utilities company. The hydropower station, completed in 1998, also feeds into the Lesotho national electricity grid, meeting $50 \%$ of national electricity demand in 2013 [75]. 


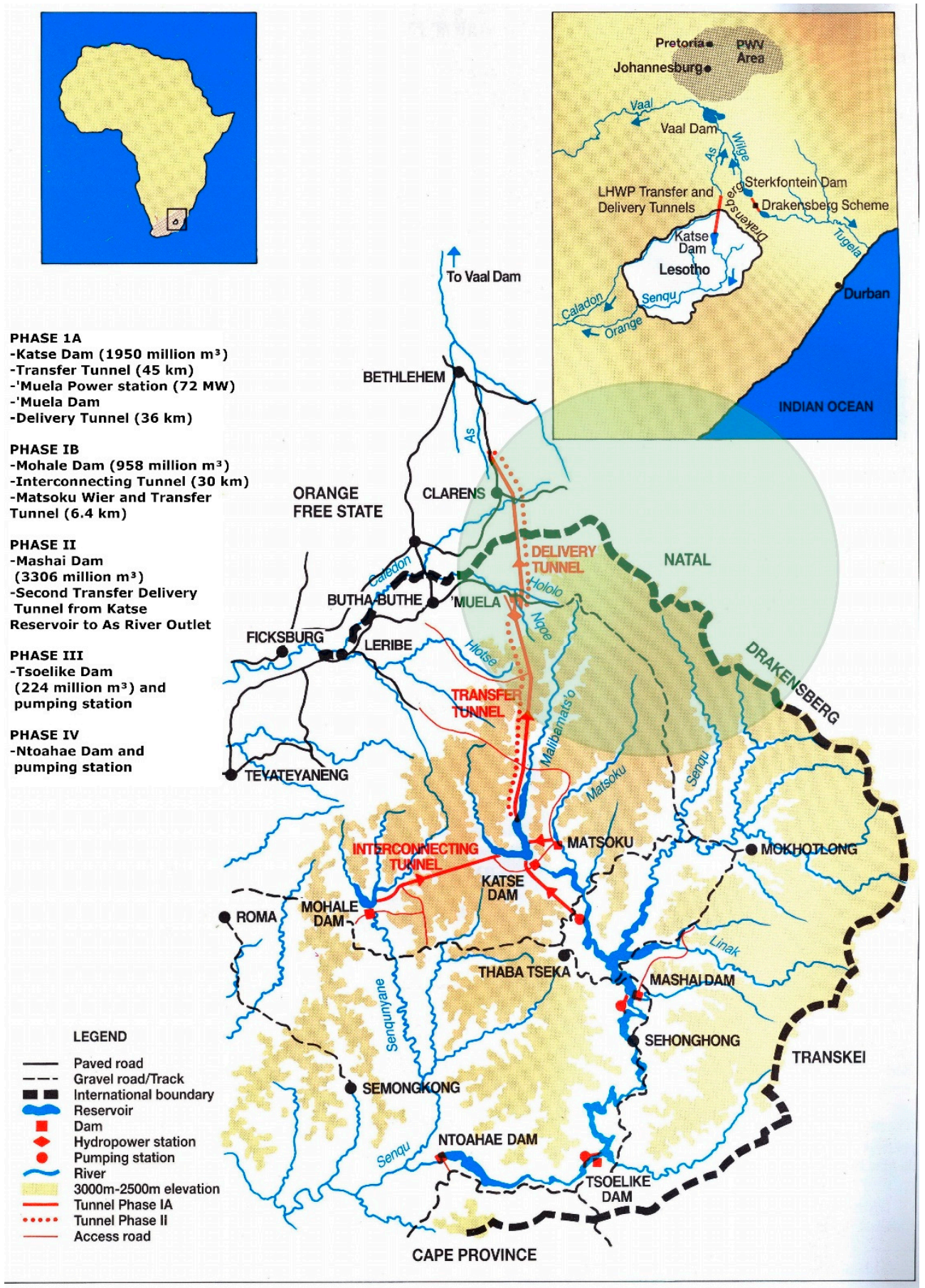

Figure 5. Map of the Lesotho Highlands Water Project (LHDA, 1995). Study area indicated in green circle.

The LHWP is controversial due to social impacts arising from such major water infrastructure. The relocation of communities from the flooded valleys for the Katse and Mohale dams - opened in 1996 and 2004, respectively (and the first two of five planned dams) - are case examples (Figure 5). In total, 573 households were relocated. ES on which local people depended were destroyed; 3825 ha of grazing land and 1800 ha of arable land were lost, overall affecting 27,400 people [76]. Material compensation has been criticised as inadequate and poorly administrated [76]. Short-sighted compensation schemes by the Lesotho Highlands Development Agency (LHDA) exposed inhabitants to poverty and food insecurity [76]. For example, lost arable land was compensated with grain hand-outs 
and lost grazing land with fodder-even though many people were resettled to urban areas or sites with no grazing for their animals [77].

The construction of the next dam, Polihali, began in 2019. A resettlement plan by the African Development Bank Group (ADBG) claims "The discussions [with affected communities] were a success, and people in the host communities were generally excited about the project and the opportunities it comes with ... " [78]. Investigations by Amnesty International, however, contradict this claim, alleging that the LHDA has failed to properly consult and compensate the 2300 households affected by the construction of the Polihali dam, due to open in 2026 [78,79]. The environmental and social impact assessment of the Polihali dam predicts 'major' long-term negative impacts due to economic displacement of affected communities, but 'major' long-term positive impacts through employment during the operational phase [65]. Amnesty International is calling for all work on the dam to be halted until it complies with human rights standards [74].

The areas affected by the LHWP provide cultural ES to local populations who attribute sacred or religious meaning to elements of living systems, meanings which were insufficiently considered by the LHDA [80]. Basotho culture revolves around village life and strong social relations based around extended family structures. In traditional Basotho culture, ancestors are revered and present a link to divinity, and land belongs to and is protected by ancestors, who must be consulted before changes in land use [80]. The social impact assessment for the Polihali dam predicts there to be 'major' short-term negative impacts on cultural heritage sites (including ancestors' graves) which the project plans to mitigate through the 'relocation' and 'demarcation' of graves, resulting in what the assessment deems to be 'minor residual impact' on cultural heritage [65]. In earlier phases of the project, many Basotho allegedly resisted resettlement, suggesting that the values they attributed to the land surpassed the material and in-kind compensation offered by the LHDA [79,80]. Many people suffered from the shock of such sudden change, the loss of livelihoods and removal from ancestral homes [74]. The trade-off between the social and economic sustainability of the Polihali dam is summarised neatly by the ADBG: "Most of the displacement is associated with the reservoir and cannot be avoided without seriously affecting the economic viability of the project." [78].

However, the LHWP also offers employment and services to local communities. The construction of the first dam (Katse) brought new infrastructure, Corporate Social Responsibility programmes (CSR), training and 7000 jobs, half of which were offered to people in the 'disadvantaged highlands' [29]. The immense artificial water system has also diversified the local economy, with small scale tourist accommodation, naturebased adventure activities and a trout farm at the Katse reservoir. The LHWP invested in infrastructure that also benefits the communities affected by the project: hundreds of kilometres of roads were built, mobile phone networks established and ventilated pit latrines built [81]. Sanitation and hygiene classes for local populations were offered by the LHDA [81]. Similar schemes are planned around the Polihali dam, currently under construction [65]. Several research papers and reports suggest, however, that the same social issues (e.g., material and spiritual loss, increased insecurity, loss of autonomy) were observed again as a result of the second LHWP dam, the Mohale Dam (opened in 2004) [82-86].

The environmental sustainability of the LHWP has been repeatedly under scrutiny in the literature. Nel and Illgner (2001) [81] report that seismic activity caused by the reservoirs have affected the water supply from springs, damaged buildings and opened cracks in the earth's surface, negatively impacting the functioning of water flow regulation ES. The first environmental impact assessment was only published in 1997 (the year following the opening of the Katse dam), and the Mohale dam assessment found far-reaching and irreversible damage to the river ecosystem [87]. Habitat destruction, species extinction, soil erosion, loss of arable land and ecosystem alterations up- and downstream are cited as the environmental impacts [87]. In addition, rangelands and wetlands will also suffer ongoing degradation due to the increased land use pressure caused by displacement from 
the reservoir [65], which could increase food insecurity and malnutrition, as seen around the Katse reservoir [86]. The long-term social sustainability of the LHWP is questionable, as jobs in construction are temporary and can raise the local cost of living. Furthermore, CSR schemes implemented around the Katse dam have since been abandoned [86].

In addition to the controversy caused by the poor social and environmental sustainability of the LHWP, there have been multiple accusations and convictions of corruption and fraud relating to the granting of construction contracts $[74,88]$.

\subsection{Rangeland}

\subsubsection{Land Tenure Regimes}

In order to understand the use and management of rangeland it is necessary to understand the two systems of governance (traditional and elected) that govern access to rangelands. These systems often find themselves at odds on both an ideological and operational level due to a fundamental disjunction in the worldviews of their associated populations. Amongst indigenous communities in both South Africa and Lesotho, land is predominantly communal and administered by local chiefs, while the state adheres to the land regime based on private ownership as introduced under colonialism. Crucially, these worldviews shape attitudes and decisions regarding land access, administration and ownership. A contentious issue is that of land access and use by local farmers in designated (or proposed) conservation areas.

Under the customary land tenure regime in Lesotho, land is valued as a common good and today's chiefs allocate land to people in their communities. The chiefs are able to administer land as if they own it but farmers have the right of access for the purposes of use which can only be revoked under specific conditions (e.g., misuse or abandonment) [39]. In the traditional conception of 'ownership' (although this word is inadequate as it does not translate across cultures), all land 'belongs' to the people or to the nation, and the rights to access and use land rests with the people [39]. This system is mirrored in South Africa, where common and communal (i.e., administered by Tribal Authorities) land is nonetheless fragmented and dominated by private property.

In the past, land reforms in both countries have sought to replace traditional land tenure with private property regimes (e.g., 1997 White Paper on South African Land Policy [89]; Land Restitution and Reform Laws Amendment Act 18 of 1999 [90]; Lesotho Land Act, 2010 [91]). In 2019, the African National Congress (ANC) government of South Africa began pursuing a policy of land expropriation and redistribution [92]. However, the reality is that, in many rural areas, traditional leaders maintain decision-making power with regards to land access $[43,93,94]$.

The repeated repeal and replacement of colonial- and apartheid-era laws has left planning laws fragmented, complicated and inconsistent [93-95]. This creates confusion today regarding the roles of traditional authorities and elected government structures at the local level where policies relating to ES access are implemented [43,94]. This legal and practical dualism has often led to conflict between rangeland users, with uncertainty over who is responsible for resolving such disputes $[39,46,55,95]$. This confusion can have various negative outcomes: the abuse of power by chiefs who claim land for their own profit; contradiction and conflict between traditional leaders and civil courts; a perceived lack of personal responsibility by individuals and thus overexploitation of resources which affects ecosystem service provision. The latter argument has been given in defence of land reforms which significantly reduced Traditional Authorities' powers over land allocation. This over exploitation of rangeland on both sides of the border negatively impacts the provision of water-related ecosystem services in the study area. Overgrazed rangelands show increasing levels of erosion, decreased infiltration and increased run-off, all which affect the functioning of water flow regulation and water provisioning ES and lead to contamination and modification of the watershed.

Problems have arisen where there has been insufficient understanding of the valuation and perspectives of local communities in policy decisions. This was exemplified by the 
land reforms in Lesotho (Land Act 2010 [91]) which removed the customary rights to land and allowed for titles to be granted. This land policy took a unidimensional valuation approach to land, recognising only its economic value and not considering the non-economic valuations associated with the ES used by local communities. The argument for the reforms were that they would offer poor farmers security of tenure. Pule and Thabane (2004) [39] argue, however, that an absence of long-term agricultural development is the result of a lack of capital to invest in agriculture, and not a result of a sense of insecurity regarding land tenure among farmers. The introduction of land titles has, in Lesotho, created two parallel systems of land administration with few linkages between them; the 'formal' state system of private ownership is superimposed on the 'informal' (i.e., communal) traditional system [39,93]. Furthermore, the Land Act 2010 [91] opened the territory to foreign and domestic acquisition, making the future of land access rights for subsistence farmers arguably more insecure since the removal of their (legally invisible) customary rights. In this context, it is unsurprising that economically weak and resource-poor farmers sell their land for cash. Furthermore, Sections 51 and 52 of the Land Act allow for "the expropriation and acquisition of land for the public interest" based on incredibly low standards and a very broad interpretation of 'public interest' and has effectively legalised the dispossession of land for 'development projects' [96]. This is particularly pertinent in the context of the land required for water transfer infrastructure discussed in Section 3.5.

It is clear that the current systems of land management are not sustainable. Environmental degradation continues in negative feedback loops, while decreasingly productive land threatens increasing numbers of people with poverty and food insecurity or pushes them to abandon their homes in search of alternative livelihoods.

\subsubsection{Animal Husbandry}

The role of livestock farming in Basotho economy, society and culture has constantly evolved in response to political-economic conditions. Ovicaprids (sheep and goats) represent provisioning ES and are produced for mohair and wool as well as for meat. They are grazed in the Lesotho highlands and, increasingly, illegally in officially protected areas in South Africa. In the Lesotho highlands, approximately half the ruminant livestock are sheep, a quarter are goats and a quarter are cattle [97].

In the absence of private property in which to invest capital, livestock offer an investment of remittances for workers in South African mines, with a herd often built up as a retirement investment [98]. However, mass retrenchment in the mines in the 1980s-1990s resulted in a shift to livestock farming as a primary source of income for many rural inhabitants. Hoag (2018) [99] goes so far as to say that ovicaprid production is now an 'economic dreamworld' for young entrepreneurial Basotho. Compared to cattle, ovicaprids grow quickly and can subsist in the harsher highland conditions. In the study area, the main meat market is in QwaQwa. Herders risk violent attacks by livestock thieves in order to smuggle their animals over the national border to buyers in the lowlands [99].

Cattle tend to be less commodified because they hold a greater symbolic value-a cultural ES-and are used more in rituals, as dowries or as symbols of wealth and prestige [100]. However, interpretations differ regarding the economic and sociocultural rationale behind the commodification of ovicaprids and the non-commodification of cattle [2,98-102]. Similarly, the roles these animals play in cultural and spiritual practices have been investigated by these same authors (and others) without consensus.

Addressing rangeland degradation should be a priority in sustainable develop initiatives, since the overexploitation of rangeland reduces biodiversity and has cascading negative impacts on a range of ES. Understanding the valuation and decision-making processes of livestock herders and owners is crucial to understanding why rangelands are perpetually overstocked, despite the obvious unsustainability of this practice, be it economically, environmentally or socially. Different theories are proposed in the literature for the apparently irrational overstocking of rangeland. Swallow et al. (1987) [98] argue that individuals sharing a communal resource do not consider the social costs inflicted by 
overgrazing, and so each individual stocks too many animals in the interest of personal profit. It could also be seen as a rational response to the circumstances and constraints of herders' socioeconomic situation: Ferguson (1994) [100] suggests that high numbers of low-quality stock may be preferential to fewer, high-quality animals when the herder's principal concern is the security and survival of the herd. Similarly, the reticence to sell stock even when fodder is scarce may be a rational appraisal of the use-value compared with the cash-value of the herd [100].

\subsubsection{The Impacts of Overgrazing}

Human communities and ecosystems downstream are also greatly affected by highland rangeland management. Overgrazing interferes with water ES provision, causing reduced soil retention, infiltration and slope stability, leading to soil run-off and the siltation of water courses and dams, water pollution and flooding downstream. Sediment is also sometimes deposited on arable or rangelands, killing off the vegetation beneath it [103].

Traditionally, the seasonal movement of livestock was controlled by traditional leaders depending on the conditions of different areas of rangeland [2,62,104], with upper slopes treated as common land and grazed sporadically in summer [62]. At the advent of colonialism, European rulers sought to reform traditional grazing regimes, introducing increasingly intense and mechanised arable farming practices and importing non-native livestock [62,63]. In South Africa, land was divided and sold privately to colonisers, fracturing and ultimately reducing communal land to $13 \%$ of the national territory [105].

The first European record of soil erosion processes in Lesotho were made in the late nineteenth century. Showers $(2005,1989)[22,63]$ cites the cutting of riparian trees by missionaries, deeper ploughing and the channels caused by makeshift dirt 'roads' as partly responsible for triggering cycles of erosion. Increased human population and agricultural activities further exacerbated this process. At the same time, colonial-imposed political and geographical demarcations interfered with traditional land management and sequestration of traditional land reduced available rangeland thereby increasing pressure on that which remained (similar to the processes of land-taking for the LHWP). These historical factors triggered cycles of environmental overexploitation, erosion and degradation which are still in motion today. In parallel, colonial powers established a political and economic system based on exploitation (of people and ES) and racism. By forcing indigenous peoples from their land (in South Africa) and imposing foreign land management and uses (in both Lesotho and South Africa), colonial settlers disrupted both the environment and the knowledge systems able to maintain it.

Nowadays, sustainable and integrated rangeland management strategies are hindered by the legal and practical dualism caused by the parallel systems of land administration discussed in Section 3.2.1. This creates confusion regarding who is responsible for managing grazing regimes. Some initiatives have been successful in increasing sustainability in rangeland management in other areas of the Drakensberg and could serve as examples of best practices, for example, the Umzimvubu Catchment Partnership Programme (www.umzimvubu.org) (accessed on 29 July 2021) and its partner, Meat Naturally (www.meatnaturallyafrica.com) (accessed on 29 July 2021). These initiatives aim at restoring and protecting rangeland ecosystems that support agricultural livelihoods and developing infrastructure to provide herders with access to meat markets.

Research is still needed to ascertain carrying capacity and provide a scientific basis for rural sustainable development strategies in the study area that address the root causes of overgrazing, which leads to far-reaching impacts on the watershed. Of equal importance is a thorough understanding of the valuation systems of land users. Management strategies will not be appropriated by herders if the perspectives that drive their decision-making are not understood and accounted for. Against this background, participatory and deliberative policy development would be necessary. 


\subsection{Conservation and Tourism}

\subsubsection{Protected Areas}

In traditional communities, the value of land is bound to its use as a common resource. This is at odds with the modern notion of private property and of protected areas, both of which establish borders and define exclusionary rights. Modern conservation, in the form of territorial exclusionary policies, has become a key cultural element of the relationship that predominantly urban societies hold with nature [106,107] and are connected to many different cultural ES. However, environmental sustainability efforts can interfere with local populations' access to cultural ESs, which support local identities through sacred sites, ceremonies and maintaining sense of place [107-109].

Conservation discourses surrounding protected areas often reflect modernity's main narratives: state bureaucratic governmentality, a dominance of science and experts, statemaking and commoditisation $[2,107]$. The protected areas of the Maloti-Drakensberg reflect this insofar as they are exclusionary areas whose aesthetic and recreational value is experienced by visitors, often at a fee. The MD protected areas were created as part of a concerted effort by the South African state to promote an image of the nation as a trailblazer of wildlife conservation in southern Africa, to improve the country's international reputation and to develop its tourism industry [110]. As such, they also represent cultural ES as "living systems that are resonant in terms of culture or heritage" [54]. In addition, these protected areas require the creation of institutional, administrative and technical/scientific capacity to manage these areas sustainably for the benefit of ES users. However, they also reflect other values, which are both use-values (e.g., the protection of water provision or the conservation of nature for recreational activities) and non-use values (e.g., carbon sequestration as a regulating ES or the conservation of nature for its existence or bequest value). As protected areas, they "enable scientific investigation" and "enable education and training" due to their high biodiversity and endemic species [26,54]. Importantly, these areas are (at least in theory) safeguarded from the overexploitation which is degrading much of the surrounding areas.

The three main South African protected areas in the study region are: Royal Natal National Park (est. 1916), Golden Gate National Park (est. 1963) and Sterkfontein Dam Nature Reserve (est. 1977). The area is also dotted with private estates and game reserves which are nationally designated nature reserves. In the study area of the Lesotho highlands there is one official protected area (Tséhlanyane National Park). Almost the entire study area falls within the Maloti-Drakensberg Transfrontier Park (MDTP).

The different entities that conceive of and manage the protected areas do so in line with their own agendas and the valuation systems of the societal groups or power structures that those entities represent. Royal Natal National Park was inscribed as part of the Maloti-Drakensberg UNESCO World Heritage Site in 2000 as a 'mixed' site based on both cultural and natural criteria. Three years later the MDTP was established, uniting preexisting protected areas under the Peace Parks initiative (www.peaceparks.org) (accessed on 5 July 2021) and created the trans-boundary Maloti-Drakensberg Park World Heritage Site. The MDTP was promoted as a tool to consolidate regional conservation knowledge as well as to foster cooperation between Lesotho and South Africa [3,21]. However, the project has been criticised by Büscher (2013) over conservation strategies which did not sufficiently consult local people or consider the social sustainability of conservation strategies. Cain (2009) [109], contracted by the MDTP in 2005-2006 to survey cultural heritage in Lesotho, cites significant limitations resulting in the under-reporting of living heritage sites-places that hold spiritual, religious and cultural value as sites of rituals, historic events and collective identity creation.

Wittmayer and Büscher (2010) [40] document the negotiation process of the MDTPproposed Liqobong park in Lesotho. Local farmers attribute use-values to the provisioning ES services used for food production, in addition to as sites of prayer, ritual and ancestors' graves, as cultural ES [40]. Wittmayer and Büscher describe how the 'local community' were treated as a homogenous group by project managers and were left feeling that their concerns 
were unaddressed. This common conservation narrative of a homogenous 'community' is reinforced by state land administration regimes which, in communal contexts, forces ownership to be vested in a single communal legal entity [93]. This merging of the varied interests of individuals obscures the community processes employed to manage and mediate interests and legally renders communities a homogenous group with regards to land administration [93].

These cases are demonstrative of the power imbalance between those implementing top-down development strategies and some ES users. This power imbalance reflects an unequal valuation of economic, environmental and social sustainability. In a global society in which economic and political power are practically synonymous, it is unsurprising that economic sustainability is given precedence in large, transboundary conservation projects. Although attempts were made address the social sustainability of MDTP policy, this seems to have been more of a symbolic gesture. The MDTP vision instead prioritised the pressing regional issue of water related ES protection, as well as economic development through tourism. There is currently an obvious paucity in research which investigates cultural ES, whereas such research could help to redress these power imbalances, by lending visibility and scientific authority to local voices.

\subsubsection{Tourism}

In a similar way that ES contributes to the cultural life of traditional communities, so does it also feed into a national narrative of South Africa as a conservation heartland. Valued as apolitical symbols of a post-apartheid South Africa, protected wildlife areas also draw tourists (and their cash) to the Maloti-Drakensberg. The tourism industry depends on cultural ES (for recreational sports, aesthetic beauty, wildlife observation and as spiritual or symbolic sites) as well as provisioning ES (freshwater production, wild animals, food production) to support its touristic offer.

Tourism is often posited as the best way to marry conservation, local development and private sector profits [111], and in so doing, addresses all three aspects of sustainability. Tourist facilities in the MD such as Witsieshoek Mountain Lodge can have benefits to the local community, providing training and employment through various skill levels. However, tourism's contribution to regional development in the MD is limited due to several factors: the relatively small size of the industry; a lack of capital investment; the concentration of tourist accommodation in one urban centre; and the often low-skilled, low-paid and seasonal nature of employment [112]. A large and wealthy segment of the tourism market resides in the town of Clarens, $60 \mathrm{~km}$ west of Phuthaditjhaba. Its economy of 'intensive leisure consumption' focuses around recreational activities in the Golden Gate Highlands National Park by wealthy White second-home owners [113]. The development benefits in terms of employment (e.g., in construction, domestic work, gardening and retail) are limited to the town and its township (Kgubetswane), where there is a surplus of low-skilled labour.

Mutana and Mukwada (2018) [114] claim that stifled development is due to insufficient engagement between tourism operators and local communities in the MD. Conservation areas cater to tourists and a local wealthy minority because of the economic value that they represent, but the social and environmental sustainability of tourism is not guaranteed. No studies have yet proposed a tourist carrying capacity for anywhere in the study area and increased visitors could in future impact negatively on the environmental sustainability of tourism in protected areas [114]. The COVID-19 pandemic has shown that tourism is not a panacea to local socioeconomic issues, and considering the ecological footprint of almost all forms of tourist consumption, it can be argued that only local, low-emission tourism is truly environmentally sustainable.

\section{Conclusions}

We have provided a novel synthesis of the major multidimensional issues in the study area, highlighting their interconnectivity and interdependence. 
The most salient research gap identified is a lack of multi- and interdisciplinarity due to the weak cooperation between scientific disciplines, particularly across social sciences/humanities (SSH) and natural sciences. Such cooperation is essential in an area where issues regarding ecosystem health, livelihoods and politics/administration are so obviously intertwined. While research in environmental sciences is strong in the MD, most prominently in biodiversity and soil sciences, if research findings are not considered in context of human-nature relations they risk fuelling conflict over development initiatives which do not sufficiently consider the needs and values of local people, as seen in the example in Section 3.7.1. Therefore, there needs to be increased opportunities for exchange and cooperation between disciplines, as well as between scientists and policy makers. Policy needs to equally consider all three aspects of sustainability and not allow dominant economic values to skew the focus of resources towards economic development. Furthermore, civil society must be meaningfully included in decision-making processes in order to build trust in governance structures, which has been eroded due historic discriminatory policies, top-down management and corruption among the political classes.

Further research gaps identified in the study area include: the monitoring and mapping of ecosystem health and ES provision, in tandem with monitoring of changes in sociocultural wellbeing; the investigation of factors driving overstocking of rangeland; the assessment of ecosystem carrying capacity in terms of livestock but also tourist numbers; mapping of areas of highest degradation and priority areas for sustainable development; a quantitative analysis of ES including research into causality, trade-offs and interaction between degradation of multiple ecosystem services.

In the Maloti-Drakensberg, pressures on ES services are considerable and negative feedback loops of degradation and overexploitation are ongoing issues. Historic and current processes have led to complex and contradictory social and political structures that govern access to ES. Furthermore, the worldviews pertaining to ES valuation, use and management differ between groups of ES users. This diversity of approach needs to be addressed in policy making and planning in order to appropriately consider power imbalances and not further marginalise under-represented groups.

The MD is an under researched area, and this paper has analysed the main multidimensional issues that concern its sustainable social, environmental and economic development. Although the lack of research in the MD may currently be seen as a barrier to effective sustainable development, the authors consider there to be strong potential for multi- and interdisciplinary research in the future which can address these issues. In this context, it is hoped that this research will provide an informative basis for future multidisciplinary research.

Author Contributions: Conceptualisation, J.L.D. and A.M.; methodology, S.S.; validation, V.R.C., J.S. and N.P.B.; data curation, J.L.D. and S.T.; writing—original draft preparation, J.L.D.; writing-review and editing, J.L.D. and S.T.; visualization, J.d.D.V.J.; supervision, V.R.C. and A.M. All authors have read and agreed to the published version of the manuscript.

Funding: This research received no external funding.

Institutional Review Board Statement: Not applicable.

Informed Consent Statement: Not applicable.

Data Availability Statement: No new data were created or analysed in this study. Data sharing is not applicable to this article.

Acknowledgments: The information and bibliographies provided by David Ambrose (National University of Lesotho) and Jacqui Taylor (Agritourism Africa) in the early stages of our research are greatly appreciated. We would particularly like to acknowledge the support provided by the Afromontane Research Unit staff and students during Andrea Membretti's visit to South Africa and Lesotho: João de Deus Vidal Jnr., Nicholas le Maitre, Retselisitsoe Albert Malefane, Anthony Mapaura and Ntebohiseng Sekhele. We also thank Royal Natal National Park and Ezemvelo KwaZulu-Natal for providing data on visitor numbers, Witsieshoek Mountain Lodge for their hospitality and Sue 
Taylor (Afromontane Research Unit) and Michele Toucher (South African Environmental Observation Network) for their valuable comments on the manuscript.

Conflicts of Interest: The authors declare no conflict of interest.

\section{References}

1. Rousselot, Y. Upstream Flows of Water: From the Lesotho Highlands to Metropolitan South Africa. Territorialities and Hydropolitics in Southern Africa. J. Alp. Res. Rev. De Géog. Alp. 2015. [CrossRef]

2. Rohde, R.F.; Moleele, N.M.; Mphale, M.; Allsopp, N.; Chanda, R.; Hoffman, M.T.; Magole, L.; Young, E. Dynamics of Grazing Policy and Practice: Environmental and Social Impacts in Three Communal Areas of Southern Africa. Environ. Sci. Policy 2006, 9 , 302-316. [CrossRef]

3. Zunckel, K. Managing and Conserving Southern African Grasslands with High Endemism: The Maloti-Drakensberg Transfrontier Conservation and Development Program. Mt. Res. Dev. 2003, 23, 113-118. [CrossRef]

4. Mountain Partnership Secretariat in collaboration with the International Climbing and Mountaineering Federation (UIAA). Declaration on Mountains and Climate Change for COP21 (2015). Twenty-First Session of the Conference of the Parties (COP21) to the United Nations Framework Convention on Climate Change (UNFCCC); UIAA: Paris, France, 2015.

5. Pepin, N.; Diaz, H.F.; Baraer, M.; Caceres, E.B.; Forsythe, N.; Fowler, H.; Greenwood, G.; Hashmi, M.Z.; Liu, X.D.; Miller, J.R.; et al. Elevation-Dependent Warming in Mountain Regions of the World. Nat. Clim. Chang. 2015, 5, 424-430. [CrossRef]

6. United Nations. Transforming Our World: The 2030 Agenda for Sustainable Development; UN: New York, NY, USA, 2015.

7. de Groot, R.; Braat, L.; Costanza, R. A short history of the ecosystem services concept. In Mapping Ecosystem Services; Burkhard, B., Maes, J., Eds.; Pensoft Publishers: Sofia, Bulgaria, 2017.

8. Millennium Ecosystem Assessment. Ecosystems and Human Well-Being: Synthesis; Island Press: Washington, DC, USA, 2005.

9. TEEB. The Economics of Ecosystems and Biodiversity: Mainstreaming the Economics of Nature: A Synthesis of the Approach, Conclusions and Recommendations of TEEB; UNEP: Nairobi, Kenya, 2010.

10. UNEP. IPBES/4/INF/1: Preliminary Guide Regarding Diverse Conceptualization of Multiple Values of Nature and Its Benefits, Including Biodiversity and Ecosystem Functions and Services (Deliverable 3(d)); Report of the Fourth Session of the Pleneray of the Intergovernmental Science-Policy Platform on Biodiversity and Ecosystem Services; UNEP: Nairobi, Kenya, 2015.

11. Haines-Young, R.; Potschin, M. Towards a Common International Classification of Ecosystem Services (CICES) for Integrated Environmental and Economic Accounting; Fabis Consulting Ltd.: Nottingham, UK, 2018.

12. World Commission on Environment and Development (WCED). Our Common Future; WCED: Cape Town, Shouth Africa, 1987.

13. Sustainable Development. UNWTO. Available online: https://www.unwto.org/sustainable-development (accessed on 24 June 2021).

14. Arthington, A.H.; Rall, J.L.; Kennard, M.J.; Pusey, B.J. Environmental Flow Requirements of Fish in Lesotho Rivers Using the Drift Methodology. River Res. Appl. 2003, 19, 641-666. [CrossRef]

15. Brown, R.W.; Summerfield, M.A.; Gleadow, A.J.W. Denudational History along a Transect across the Drakensberg Escarpment of Southern Africa Derived from Apatite Fission Track Thermochronology. J. Geophys. Res.-Solid Earth 2002, 107, 2350. [CrossRef]

16. Thekisoe, M.M.O.; Mbati, P.A.; Bisschop, S.P.R. Different Approaches to the Vaccination of Free Ranging Village Chickens against Newcastle Disease in Qwa-Qwa, South Africa. Vet. Microbiol. 2004, 101, 23-30. [CrossRef]

17. Plug, I.; Mitchell, P. Fishing in the Lesotho Highlands: 26,000 Years of Fish Exploitation, with Special Reference to Sehonghong Shelter. J. Afr. Archaeol. 2008, 6, 33-55. [CrossRef]

18. Tilt, B.; Braun, Y.; He, D. Social Impacts of Large Dam Projects: A Comparison of International Case Studies and Implications for Best Practice. J. Environ. Manag. 2009, 90, S249-S257. [CrossRef]

19. Slater, R. Differentiation and Diversification: Changing Livelihoods in Qwaqwa, South Africa, 1970-2000. J. South. Afr. Stud. 2002, 28, 599-614. [CrossRef]

20. Challis, S. Creolisation on the Nineteenth-Century Frontiers of Southern Africa: A Case Study of the AmaTola "Bushmen" in the Maloti-Drakensberg. J. South. Afr. Stud. 2012, 38, 265-280. [CrossRef]

21. Büscher, B. Transforming the Frontier: Peace Parks and the Politics of Neoliberal Conservation in Southern Africa; Duke University Press: Durham, UK; London, UK, 2013.

22. Showers, K.B. Imperial Gullies: Soil Erosion and Conservation in Lesotho, 1st ed.; Ohio University Press: Athens, OH, USA, 2005; ISBN 978-0-8214-1614-3.

23. Blignaut, J.; Mander, M.; Schulze, R.; Horan, M.; Dickens, C.; Pringle, C.; Mavundla, K.; Mahlangu, I.; Wilson, A.; McKenzie, M.; et al. Restoring and Managing Natural Capital towards Fostering Economic Development: Evidence from the Drakensberg, South Africa. Ecol. Econ. 2010, 69, 1313-1323. [CrossRef]

24. Blignaut, J.; Aronson, J.; Mander, M.; Marais, C. Investing in Natural Capital and Economic Development: South Africa's Drakensberg Mountains. Ecol. Restor. 2008, 26, 143-150. [CrossRef]

25. Nel, J.L.; Le Maitre, D.C.; Roux, D.J.; Colvin, C.; Smith, J.S.; Smith-Adao, L.B.; Maherry, A.; Sitas, N. Strategic Water Source Areas for Urban Water Security: Making the Connection between Protecting Ecosystems and Benefiting from Their Services. Ecosyst. Serv. 2017, 28, 251-259. [CrossRef]

26. Carbutt, C. The Drakensberg Mountain Centre: A Necessary Revision of Southern Africa's High-Elevation Centre of Plant Endemism. S. Afr. J. Bot. 2019, 124, 508-529. [CrossRef] 
27. Clark, V.R.; Barker, N.P.; Mucina, L. The Great Escarpment of Southern Africa: A New Frontier for Biodiversity Exploration. Biodivers. Conserv. 2011, 20, 2543. [CrossRef]

28. BoS. 2010/2011 Household Budget Survey. Analytical Report Volume 1; Lesotho Bureau of Statistics: Maseru, Lesotho, 2014.

29. Scholvin, S. Key Projects of Regional Integration. In The Geopolitics of Regional Power: Geography, Economics and Politics in Southern Africa; Routledge: New York, NY, USA, 2016; ISBN 978-1-315-55771-7.

30. Makhoalibe, S. Management of Water Resources in the Maloti/Drakensberg Mountains of Lesotho. Ambio 1999, $28,460-461$.

31. World Bank. Poverty Headcount Ratio at National Poverty Lines (\% of Population); The World Bank Group: Wasighton DC, USA, 2020.

32. BoS. Population and Housing Census 2016; Bureau of Statistics: Maseru, Lesotho, 2016.

33. World Economic Forum. Global Gender Gap Report 2020; World Economic Forum: Geneva, Switzerland, 2020.

34. Colvin, C.; Imelda, H.; Nel, J.; Le Maitre, D.; Smith, J. Defining South Africa's Water Source Areas; WWF-SA: Newlands, South Africa, 2013.

35. StatsSA GHS Series Volume VIII. Water and Sanitation. In-Depth Analysis of the GHS 2002-2015 and CS 2016 Data; Statistics South Africa: Pretoria, South Africa, 2016.

36. Comaroff, J. Reflections on Liberalism, Policulturalism, and ID-Ology: Citizenship and Difference in South Africa. Soc. Identities 2003, 9, 445-473. [CrossRef]

37. Lehohla, P. Provincial Profile: Free State; Statistics South Africa: Pretoria, South Africa, 2011.

38. Lehohla, P. Provincial Profile: KwaZulu-Natal; South African Statistics: Pretoria, South Africa, 2011.

39. Pule, N.W.; Thabane, M. Lesotho's Land Tenure Regimes: Experiences of Rural Communities and the Calls for Land Reform. J. Mod. Afr. Stud. 2004, 42, 283-303. [CrossRef]

40. Wittmayer, J.M.; Büscher, B. Conserving Conflict? Transfrontier Conservation, Development Discourses and Local Conflict Between South Africa and Lesotho. Hum. Ecol. 2010, 38, 763-773. [CrossRef]

41. Cobbing, J. The Mfecane as Alibi: Thoughts on Dithakong and Mbolompo. J. Afr. Hist. 1988, 29, 487-519. [CrossRef]

42. Union of South Africa. Promotion of Bantu Self-Governing Act; Union of South Africa: Pretoria, South Africa, 1959.

43. Khunou, S.F. Traditional Leadership and Independent Bantustans of South Africa: Some Milestones of Transformative Constitutionalism beyond Apartheid. PER Potchefstroomse Elektron. Regsblad 2009, 12, 81-122.

44. Iliffe, J. The African Poor: A History; Cambridge University Press: Cambridge, UK, 1987; ISBN 978-0-521-34877-5.

45. Modiba, I. More than R2 Billion Needed to Solve Maluti-A-Phofung Water Crisis: Sisulu. Available online: https: //www.sabcnews.com/sabcnews/more-than-r2-billion-needed-to-solve-maluti-a-phofung-water-crisis-sisulu/ (accessed on 13 April 2020).

46. Diederichs, N.; Mander, M. Payment for Environmental Services Baseline Study; FutureWorks! Everton: New York, NY, USA, 2004.

47. Blignaut, J.N.; Marais, C.; Turpie, J.K. Determining a Charge for the Clearing of Invasive Alien Plant Species (IAPs) to Augment Water Supply in South Africa. Water SA 2007, 33, 27-34. [CrossRef]

48. Turpie, J.K.; Marais, C.; Blignaut, J.N. The Working for Water Programme: Evolution of a Payments for Ecosystem Services Mechanism That Addresses Both Poverty and Ecosystem Service Delivery in South Africa. Ecol. Econ. 2008, 65, 788-798. [CrossRef]

49. Büscher, B. Selling Success: Constructing Value in Conservation and Development. World Dev. 2014, 57, 79-90. [CrossRef]

50. Chatanga, P.; Kotze, D.C.; Janks, M.; Sieben, E.J.J. Classification, Description and Environmental Factors of Montane Wetland Vegetation of the Maloti-Drakensberg Region and the Surrounding Areas. South Afr. J. Bot. 2019, 125, 221-233. [CrossRef]

51. Chatanga, P.; Seleteng-Kose, L. Montane Palustrine Wetlands of Lesotho: Vegetation, Ecosystem Services, Current Status, Threats and Conservation. Wetlands 2021, 41, 67. [CrossRef]

52. Matchaya, G.; Nhamo, L.; Nhlengethwa, S.; Nhemachena, C. An Overview of Water Markets in Southern Africa: An Option for Water Management in Times of Scarcity. Water 2019, 11, 1006. [CrossRef]

53. Coldrey, K.; O'Connor, T.; Rushworth, I.; Carbutt, C.; Manson, A. UKhahlamba Drakensberg Park Climate Change Predictions, Impacts, Vulnerability and Adaptation; Unpublished; 2019.

54. Haines-Young, R.; Potschin, M.B. Common International Classification of Ecosystem Services (CICES) V5.1 and Guidance on the Application of the Revised Structure; European Environment Agency (EEA): Copenhagen, Denmark, 2018.

55. Driver, T. Anti-Erosion Policies in the Mountain Areas of Lesotho: The South African Connection. Environ. Hist. 1999, 5, 1-25. [CrossRef]

56. IPCC. Ecosystems and Their Goods and Services. In TAR Climate Change 2001: Impacts, Adaptation, and Vulnerability; IPCC: Geneva, Switzerland, 2001.

57. ORASECOM. Rehabilitating Rangelands for Healthy Headwaters: Steps Basotho Communities Are Taking to Reverse Land Degradation at the Source of the Orange-Senqu River; Orange-Senqu River Commission: Pretoria, South Africa, 2014.

58. Quinlan, T.; Morris, C.D. Implications of Changes to the Transhumance System for Conservation of the Mountain Catchments in Eastern Lesotho. Afr. J. Range Forage Sci. 1994, 11, 76-81. [CrossRef]

59. Hamer, M.; Slowtow, R. A Comparison and Conservation Assessment of the High-Altitude Grassland and Forest-Millipede (Diplopoda) Fauna of the South African Drakensberg. Soil Org. 2009, 81, 701-717.

60. Kopij, G. Avian Assemblages in Afro-Mountain and Alti-Mountain Grasslands in the Endemic Maloti/Drakensberg Region of Lesotho. Zool. Ecol. 2015, 25, 319-326. [CrossRef]

61. Kopij, G. Lepidoptera Fauna of Lesotho. Acta Zool. Crac. 2006, 49, 137-180. [CrossRef]

62. Quinlan, T. Grassland Degradation and Livestock Rearing in Lesotho. J. South. Afr. Stud. 1995, 21, 491-507. [CrossRef] 
63. Showers, K.B. Soil Erosion in the Kingdom of Lesotho: Origins and Colonial Response, 1830s-1950s. J. South. Afr. Stud. 1989, 15, 263-286. [CrossRef]

64. Slater, R. Between a Rock and a Hard Place: Contested Livelihoods in Qwaqwa National Park, South Africa. Geogr. J. 2002, 168, 116-129. [CrossRef]

65. African Development Bank Group. Lesotho Highland Water Project Phase II. Environmental E Social Impact Assessment. Summary for Polihali Reservoir \& Associated Infrastructure. 2019. Available online: https://www.afdb.org/en/documents/document/lesotholesotho-highland-water-project-phase-ii-lhwpii-polihali-reservoir-associated-infrastructure-esia-summary-108571 (accessed on 29 July 2021).

66. Cambray, J.A. The Global Impact of Alien Trout Species-A Review; with Reference to Their Impact in South Africa. Afr. J. Aquat. Sci. 2003, 28, 61-67. [CrossRef]

67. Karssing, R.J.; Rivers-Moore, N.A.; Slater, K. Influence of Waterfalls on Patterns of Association between Trout and Natal Cascade Frog Hadromophryne Natalensis Tadpoles in Two Headwater Streams in the UKhahlamba Drakensberg Park World Heritage Site, South Africa. Afr. J. Aquat. Sci. 2012, 37, 107-112. [CrossRef]

68. Carbutt, C.; Edwards, T. Plant-Soil Interactions in Lower-Upper Montane Systems and Their Implications in a Warming World: A Case Study from the Maloti-Drakensberg Park, Southern Africa. Biodiversity 2016, 16, 262-277. [CrossRef]

69. Roux, J.L.; Morgenthal, T.L.; Malherbe, J.; Pretorius, D.J.; Sumner, P.D. Water Erosion Prediction at a National Scale for South Africa. Water SA 2008, 34, 305-314. [CrossRef]

70. Otieno, F.A.O.; Ochieng, G.M.M. Water Management Tools as a Means of Averting a Possible Water Scarcity in South Africa by the Year 2025. Water SA 2004, 30, 120-124. [CrossRef]

71. UNDCWS. United Nations World Water Development Report 4. Volume 1: Managing Water under Uncertainty and Risk; United Nations Educational, Scientific and Cultural Organization (UNESCO), United Nations World Water Assessment Programme (WWAP), UN-Water: New York, NY, USA, 2012.

72. Blignaut, J.N.; Van Heerden, J.H.; Jan, H. The Impact of Water Scarcity on Economic Development Initiatives. Water Sa 2009, 34, 5. [CrossRef]

73. Mwangi, O. Hydropolitics, Ecocide and Human Security in Lesotho: A Case Study of the Lesotho Highlands Water Project. J. South. Afr. Stud. 2007, 33, 3-17. [CrossRef]

74. Keketso, L. The Mixed Blessings of the Lesotho Highlands Water Project. MRED 2003, 23, 7-10. [CrossRef]

75. Ministry of Energy and Meteorology. Lesotho Energy Policy 2015-2025; Ministry of Energy and Meteorology: Maseru, Lesotho, 2015.

76. Hitchcock, R.K. The Lesotho Highlands Water Project: Dams, Development, and the World Bank. Sociol. Anthropol. 2015, 3, 526-538. [CrossRef]

77. Mashinini, V. The Lesotho Highlands Water Project and Sustainable Livelihoods: Policy Implications for SADC; 2010. Available online: https: / / www.africaportal.org/publications / the-lesotho-highlands-water-project-and-sustainable-livelihoods-policyimplications-for-sadc/ (accessed on 29 July 2021).

78. African Development Bank Group. Resettlement Action Plan Summary for the Lesotho Highland Water Project Phase II; African Development Bank Group: Centurion, South Africa, 2019.

79. Amnesty International: Lesotho. 8000 People at Risk of Displacement in Lesotho Due to Water Deal with South Africa; Amnesty International: Tyoko, Japan, 2020.

80. Rakotsoane, F.C. The Southern Sotho's Ultimate Object of Worship: Sky Divinity or Water Divinity? Ph.D. Thesis, University of Cape Town, Cape Town, South Africa, 2001.

81. Nel, E.; Illgner, P. Tapping Lesotho's "White Gold”: Inter-Basin Water Transfer in Southern Africa. Geography 2001, 86, 163-167.

82. Thamae, M.L.; Pottinger, L. Transformation. On the Wrong Side of Development: Lessons Learned from the Lesotho Highlands Water Project; Transformation Resource Centre: Maseru, Lesotho, 2006; ISBN 978-99911-32-01-3.

83. Transforming Society through Advocacy for Justice: Case Histories of Communities Impacted by the Lesotho Highlands Water Project: Phase 1B: Mohale Dam Project; Thamae, M.L.; Transformation (Organization) (Eds.) Transformation Resource Centre: Maseru, Lesotho, 2015; ISBN 978-99911-32-03-7.

84. The New Humanitarian; 11 November 2011. Available online: https://www.thenewhumanitarian.org/news/2011/11/11 /government-optimistic-about-peace-talks-despite-fighting (accessed on 29 July 2021).

85. Lenka, T. The Irony of Development: Communities Impacted by the Lesotho Highlands Water Project. 2020. Available online: https: / / www.google.com.hk/url?sa=t\&rct=j\&q=\&esrc=s\&source=web\&cd=\&ved=2ahUKEwjn7arW1onyAhURNuwKHcacC8 kQFjAAegQIAxAD\&url=https\%3A\%2F\%2Fwww.protimos.org\%2Fuploads\%2F6\%2F6\%2F2\%2F1\%2F6621888\%2Fthe_irony_ of_development_1_thamae.pdf\&usg=AOvVaw31ZeC54Gwygk97EqsgpVhD (accessed on 29 July 2021).

86. Letsebe, P.H. A Study of the Impact of Lesotho Highlands Water Project on Residents of Khohlo-Ntso: Is It Too Late for Equitable Benefit Sharing? Master's Thesis, University of the Witwatersrand, Johannesburg, South Africa, 2013.

87. LHDA. Lesotho_-Highlands Water Project_Phase B: Environmental Impact Assessment; World Development Sources; The World Bank: Washington, DC, USA, 1997.

88. Darroch, F. The Lesotho Corruption Trials-A Case Study. Commonw. Law Bull. 2003, 29, 901-975. [CrossRef]

89. DLA. White Paper on South African Land Policy1997. Available online: https://www.sahistory.org.za/archive/white-papersouth-african-land-policy-april-1997 (accessed on 29 July 2021). 
90. Land Restitution and Reform Laws Amendment Act 18 of 1999; $406 \S 19968$; Republic of South Africa: Johannesburg, South Africa, 1999.

91. Land Act, 2010 (Act No. 8 of 2010); Volume LV, No. 42; Paliament of Lesotho: Maseru, Lesotho, 2010.

92. National Assembly Proposed Section 74(2). Consitution Eighteenth Amendment Bill; initiated by the Ad Hoc Committee on the amendment of section 25 of the Constitution of the Republic of South Africa, 1996; National Assembly: Cape Town, South Africa, 2019.

93. Alcock, R.; Hornby, D. Traditional Land Matters-A Look into Land Administration in Tribal Areas in KwaZulu-Natal. Legal Entity Assessment Project. 2004, p. 35. Available online: https:/ / mokoro.co.uk/land-rights-article/traditional-land-matters-a-lookinto-land-administration-in-tribal-areas-in-kwazulu-natal/ (accessed on 29 July 2021).

94. Logan, C. Selected Chiefs, Elected Councillors and Hybrid Democrats: Popular Perspectives on the Co-Existence of Democracy and Traditional Authority. J. Mod. Afr. Stud. 2009, 47, 101-128. [CrossRef]

95. Clark, M.; Luwaya, N. Communal Land Tenure 1994-2017: Commissioned Report for High Level Panel on the Assessment of Key Legislation and the Acceleration of Fundamental Change, an Initiative of the Parliament of South Africa; Land and Accountability Research Centre: Cape Town, South Africa, 2017.

96. Fogelman, C. Development by Dispossession: The Post-2000 Development Agenda and Land Rights in Lesotho. Afr. Geogr. Rev. 2018, 37, 257-272. [CrossRef]

97. Bureau of Statistics. Lesotho Livestock Statistics Report 2013/2014; Bureau of Statistics: Maseru, Letsotho, 2015.

98. Swallow, B.M.; Brokken, F.R.; Motsamai, M.; Sopeng, L.; Storey, G.G. Livestock Development and Range Utilization in Lesotho; 1987. Available online: https:/ / opendocs.ids.ac.uk/opendocs/handle/20.500.12413/5974 (accessed on 29 July 2021).

99. Hoag, C. The Ovicaprine Mystique: Livestock Commodification in Postindustrial Lesotho. Am. Anthropol. 2018, 120, 725-737. [CrossRef]

100. Ferguson, J. The Anti-Politics Machine; University of Minnesota Press: Minneapolis, MN, USA, 1994; ISBN 978-0-8166-2437-9.

101. Ashton, H. The Basuto: A Social Study of Traditional and Modern Lesotho; Routledge: New York, NY, USA, 2018; ISBN 978-1-351-04306-9.

102. Turkon, D. Modernity, Tradition and the Demystification of Cattle in Lesotho. Afr. Stud. 2003, 62, 147-169. [CrossRef]

103. Preez, P.J.D.; Brown, L.R. Impact of Domestic Animals on Ecosystem Integrity of Lesotho High Altitude Peatlands. In Ecosystems Biodiversity; Grillo, O., Venora, G., Eds.; InTech: Rijeka, Croatia, 2011.

104. Orasecom Demographic and Economic Activity in the Four Orange Basin States. Orange River Integrated Water Resource Management Plan; 2007. Available online: https://www.google.com.hk/url?sa=t\&rct=j\&q=\&esrc=s\&source=web\&cd= \&ved=2ahUKEwj3hvi-04nyAhWHyosBHcz1Co8QFjAAegQIAxAD\&url=http\%3A\%2F\%2Fwww.orasecom.org\%2F_system\% 2Fwritable\%2FDMSStorage\%2F1941DEMOGRAPHICS.PDF\&usg=AOvVaw1nVkILPYsEMMW5IBnkQKIX (accessed on 29 July 2021).

105. Collins, R.O.; Burns, J.M. A History of Sub-Saharan Africa; Cambridge University Press: Cambridge, UK, 2007; ISBN 978-0-521-86746-7.

106. Latour, B. Nous N'avons Jamais Été Modernes. Essai D'anthropologie Symétrique; La Decouverte Editions: Paris, France, 2007; ISBN 978-2-7071-2692-4.

107. Vaccaro, I.; Beltran, O.; Paquet, P.A. Political Ecology and Conservation Policies: Some Theoretical Genealogies. J. Political Ecol. 2013, 20, 255-272. [CrossRef]

108. Pascual, U.; Balvanera, P.; Díaz, S.; Pataki, G.; Roth, E.; Stenseke, M.; Watson, R.T.; Başak Dessane, E.; Islar, M.; Kelemen, E.; et al. Valuing Nature's Contributions to People: The IPBES Approach. Curr. Opin. Environ. Sustain. 2017, 26-27, 7-16. [CrossRef]

109. Cain, C.R. Cultural Heritage Survey of Lesotho of the Maloti-Drakensberg Transfrontier Project, 2005-2006: Palaeontology, Archaeology, History and Heritage Management. South Afr. Archaeol. Bull. 2009, 64, 33-44.

110. Witz, L.; Rassool, C.; Minkley, G. Repackaging the Past for South African Tourism. Daedalus 2001, 130, $277-296$.

111. Igoe, J.; Brockington, D. Neoliberal Conservation: A Brief Introduction. Conserv. Soc. 2007, 5, 432.

112. Halseth, G.; Meiklejohn, C. Indicators of Small Town Tourism Development Potential: The Case of Fouriesburg, South Africa. Urban Forum 2009, 20, 293. [CrossRef]

113. Hoogendoorn, G. Second Homes and Local Economic Impacts in the South African Post-Productivist Countryside. Ph.D.Thesis, University of the Free State, Bloemfontein, South Africa, 2010.

114. Mutana, S.; Mukwada, G. Can Mountain Route Tourism Work for the Poor? Exploring Worldviews from Maluti Route in the Drakensberg Region of South Africa. Tour. Hosp. Res. 2018, 1467358418791312. [CrossRef] 